\title{
USE OF WATERWAY TRANSPORT INTEGRATED TO URBAN TRANSPORTATION SYSTEMS IN AMAZONIAN CITIES: A VISION OF SUSTAINABLE MOBILITY
}

\author{
MAISA SALES GAMA TOBIAS ${ }^{1}$, RUI ANTÓNIO RODRIGUES RAMOS ${ }^{2}$ \\ $\&$ DANIEL SOUTO RODRIGUES ${ }^{2}$ \\ ${ }^{1}$ Institute of Technology, University of Para, Brazil \\ ${ }^{2}$ Escola de Engenharia, Universidade do Minho, Portugal
}

\begin{abstract}
Over time, in Amazonia, water transportation became a penetration and occupation vector, defining flows over the region by settlement locations and influencing the supply process of either freight or passengers. However, in urban areas with river fronts, road transport prevailed, wasting the potential offered by water transport. This could be used as complementary, integrated, and, therefore, be a factor of social inclusion and promotion of sustainable mobility. In this article, an exploratory study of integrated intermodal transport was undertaken, in a strategic planning vision for Belem, Brazil, based on literature review, using databases of transport surveys from pre-existing studies and on-site observation of the city of Belem. The challenges were discussed in terms of an analysis scale covering integration dimensions, as well as presenting a possible intermodal network, integrating urban and water transportation. Among the results, it was noted that on the mainland, water transportation is desirable, to escape from urban road traffic, reducing costs and minimizing travel times. It was also observed that all Belem areas with one interconnecting road, regardless of distance and travel time to downtown, are more developed and, therefore, more valued than the insular areas; therefore it is supposed that an intermodal network could improve accessibility for islands' population, promoting social inclusion. In general, the use of water transport integrated to global urban transportation systems seems possible, but there are many questions to be solved in the implementation of that mode in Belem. Keywords: water transport, integration, cities, sustainability, mobility.
\end{abstract}

\section{INTRODUCTION}

The concept of integrated transport has become an important guiding principle for undertaking institutional and structural transport policies in several countries. It is now widely recognized that policies, which allow for increased mobility, especially, by car are manifestly unsustainable [1], [2]. The adverse impacts of road travel include congestion; noxious emissions and air quality deterioration; global warming $\left(\mathrm{CO}^{2}\right.$ emissions $)$; use of nonrenewable resources; casualties of accidents; damage to health and insecurity; noise and vibration; social polarization and public expense. The last decades have seen the recognition that policies to manage the volume of car travel are inevitable.

Situations like this, related to supremacy of auto in large urban centers and its adverse effects, led to sustainable development studies for cities, to reverse the situation and bring quality of life to people. Until then, there were many articles about sustainable development without any explicit linkages to mobility or transport. Similarly, the mobility concept addressed without linkages to a sustainable development. Consequently, mobility could be defined as a function of two variables. The first one, the tangible realization of travel needs in the form of actual movements. The other one, referred as the potential for movement, a personal or group categorization, functioning as a limitation of the first variable [3]. However, transport growth generated increasing environmental impacts hardened by the growing share of road transportation [4] and traditional approaches to cope with the transport growth, such as predict and provide strategies, were no longer sustainable options. Mainly, 
due to the induced demand by enlarged infrastructure capacity [5], being proposed approaches combining demand and supply of transport with other types of instruments and analysis levels; they have been potentially better approaches [6].

OECD stated that technological improvements and innovation must be pursued, but alone are not the solution [7]. Integration was much harder to define as it can encompass so many different things, many different actions could be thought of as representing an integrated approach. In other words, it was worthwhile to consider different approaches to transport integration, considering what exactly was integrated with what? Wherein integrated transport was better viewed as scalar in nature, with higher levels incorporating lower levels. Essentially the highest-level holistic strategy may be described as that which brings together all of the perspectives in a coherent way. While such a strategy contains little that is new, the high level of integration between different policy strands as aim is to ensure that environmental, economic and transport policy measures are working in harmony to reduce the need for travel, and reduce the impact of journeys made.

Many elements in social, economic, environmental, transport and land use policies are integrated in such a way that the whole system has a greater value than the sum of the parts. This is a systems led or holistic approach [8], [9]. This level provides the best opportunity for a more sustainable transport system and is the benchmark against which all integrated transport strategies should be tested. A further development would be to integrate transport policy into key social policy areas to include those who use and provide transport systems, and others with a stake in transport who are not usually involved, such who suffer transport generated noise and vibration. Also involved would be those who operate trip-generating sites, who would be asked to consider the travel impact of their operations. Particular examples, within the public sector, include health and education services [10].

Summing up, sustainability and integration ideas have evolved from concerns about the environmental impact, new and existing, voiced within the land use planning system, to incorporate social, economic, and sometimes ethical perspectives. Sustainable development practice requires that economic growth simultaneously supports the needs of everyone and conserves natural resources, and that social policy underpins economic performance and complements environmental policy. In this context, they can be seen several works on the concepts of sustainable mobility, theories and models, making it the central theme of planning and a paradigmatic element in policies for the transformation and urban regeneration [11]-[13].

Several projects in the world raised from the conception of integrating urban spaces, based on strategies and policies for sustainable urban development, with investments in the urban regeneration of waterfronts - in Rotterdam, Barcelona, Liverpool, Valencia, Vancouver, Tokyo, Hamburg, Amsterdam, Genoa, Glasgow, Antwerp, Copenhagen, etc. - are wellknown experiences. They can be interpreted as transition experiments [14] and express the creativity and resilience of cities against the pressures of change, by highlighting the capability of cities to transform themselves and to maintain their identity. In recent years, with globalization phenomenon, cities in internationally have undergone radical transformations - both physically and conceptually - in the way the territory is inhabited and experienced. The changes have involved ways and means to circulate through the urban spaces; the concept of border has itself progressively lost and relationships between public and private spaces have changed. The contemporary cities, complex and stratified, have been transformed into shapes, structures and uses [15], [16].

Within this vision of sustainable mobility, this article developed an exploratory study of integrated intermodal transport, in a strategic planning vision, in Belem, Brazil, based on literature review, using databases of transport surveys from preexisting studies and on-site 
observation of Belem. It was discussed the challenges in terms of analysis scale covering integration dimensions, as well as presenting a possible intermodal network, integrating urban and water transportation. Strategic approach was focused on physical and environmental factors, a spatial vision, with emphasis on urban mobility and land use, however, noting the economic and social issues involving the downtown and the periphery areas, including islands. Finally, this article reported the challenges in using of water transport integrated to urban transportation system, in special, in Amazonia city, as way to promote sustainability in central areas, in addition to social inclusion to peripheral areas.

\section{ANALYTICAL THEORETICAL BASES}

Strategic planning vision in urban mobility passes by challenges of meet the people needs on social, economic, environmental and political levels, to bring about a significant shift from the car to other ways of travelling, such as walking, cycling and public transport. The studies shows a range of types of integration, and highlight the problems in developing an effective integrated strategy, given the number of variables involved [17], [18]. Thus, this article started from the premise that integration should be designed to serve agreed objectives of transport policy, rather than being an objective in its own right. Successfully implementing this strategy will lead to: greater social equity; more efficient transport for both people and freight; less pollution caused by transport; better air quality and less noise. This means an analysis of transport network integration covering variables of land use and operational efficiency of transport, encompassing minimization of environmental impacts and technological adequacy, towards a more ecologically suitable environment.

Therefore, the methodological approach of this study was based on the construction of intermodal transport network in order to all people should be able to move around conveniently and safely; reducing the number, length and need to make journeys; whilst reducing journeys by car and promoting a healthier lifestyle. Based on the existing studies, whose list was not intended to be exhaustive, however, within the vision of sustainable mobility planning, a scale of analysis covering four dimensions of integration was proposed:

i) Modal dimension: allows analysis of the integration of existing modes, defined as the integration of some or all of the different public transport modes (mainly trains, buses, taxis and boats) into the public transport system. These modes support and complement each other and operate as a coordinated public transport system, while providing an effective efficient and affordable service to the user. To implement integrated transportation system, the following aspects should be achieved in a project, preferably as many as possible: an integrated network, proper transfer facilities, a common ticketing and fare system, through an information system. Modal transport integration must be so developed as to give higher priority to public transport than private transport by ensuring the provision of adequate public transport services to discourage private transport [19]. An effective modal integration system should meet on movement of people; in cooperation among and support of different government levels; on availability of funds and on clarity of government policy; in formalization and regulation of transportation, with institutional proper framework and proper planning.

ii) Transport and land use dimension: linked, intrinsically, by the direct influence that has the land use in the generation of trips. New transportation infrastructure can help shape land uses by increasing the accessibility of spaces and the mobility of users [20]. In addition, the new interaction of flows offers to some existing user time saving on highway network over their current routes and destination, thereby increasing 
demand for new development on these spaces. These pressures can result in land development around and require improving mobility and producing powerful effects on land use; as other transportation investments can produce induced growth, in similar way.

iii) Social dimension: related to interests of all those in need of transport, it is important concern for sustainable mobility [21]. Lack of access and mobility prevents people from being able to break out of the cycle of social exclusion. Transport is a derived demand; it is not normally an end in itself but a means to realize other activities, which the end that it supports is the provision of access to activities of all kinds. The concern is whether people can access key services at reasonable costs, in reasonable time and with reasonable ease. The social dimension of transport is underpinned by three values and principles namely equity, accessibility and mobility [22].

iv) Environmental, economic and transport policies dimension in a holistic perspective: policies are referred to as bottom analysis for a sustainable transport, observing environmental dimensions in impacts of human activities on changing local and global environments. Economy development is the process of a community's growth or progress towards economic goals, such as increased wealth, employment, productivity or ultimately welfare. The specific focus on environmental and economic issues should be used to decision making in transportation on levels of analysis, being governance, funding and infrastructure [23], [24].

\section{A CASE IN AMAZONIA: BELEM INTEGRATION ON A SUSTAINABLE MOBILITY VISION}

In Amazonia, the first cities emerged from early expeditions of colonizers to its rivers. Economy is based on tourism, trade and services activities but, outside urban areas, agriculture and fishing are predominant. In general, the urban morphology is radial, with downtown located in the initial historic part, along the waterfront [25]. The most important regional transportation mode is the boat, and in urban areas are other modes of transportation, mainly motorcycles and cars. In this universe, the city of Belem, in Brazil northern region, is a typical Amazonian city with an important waterfront, capital of a Metropolitan Region of the same name, gateway of Amazon. Capital of Para state, with 1.5 million population; it is located in a peninsula, in front of Guajara Bay, and comprises two sectors: mainland and islands.

\subsection{Modal dimension}

At the city and region initial foundation, in the 17th century, the main mode of transport in Belem was the waterway transport. This mode of transportation was predominant for intraurban connections, for four centuries and, in the urban area, motorized and no motorized modes were used for small distances. There was an isolated railroad initiative linking Belem to others cities, which was closed in the first part of the last century. Even, in the last century, there was introduction of trams in urban areas, but at first decades in the century, only. The impulse in urban transport came to occur after World War II, when trams were replaced by buses. The spatial configuration of public transport by bus followed and it was determinant in the process of urban occupation. After the buses and the boats to islands, came individual modes of public transportation, such as taxis, moto taxis and vans. A special feature is the fact that the transport system is multimodal, but without integration. Urban centralities, which constituted over urban occupation, proved responsible for the evolution and intensity of transport flows and the consequent development of the road network in recent decades [26]. 
However, without focus on people displacements; without proper cooperation and support from different levels of government; without the availability of financing funds for transportation and without the clarity of government policy, or in the formalization and regulation of transportation, lacking the adequate institutional structure and proper planning [27]. Currently, the integrated system is at the level of plan and project, without effectiveness neither large variations in modal split into public transport [28], as can be seen in Table 1.

Table 1: Modal split of transportation in Belem. (Source: JICA/SEDURB/COHAB, 2009.)

\begin{tabular}{|c|c|c|c|}
\hline Year & Private & Public & Total \\
\hline 2009 & $1,043.252$ & $1,724.093$ & $2,767.345$ \\
\hline 2013 & $1,225.666$ & $1,859.999$ & 3.085 .665 \\
\hline 2018 & $1,504.806$ & $2,006.348$ & $3,511.154$ \\
\hline 2025 & $1,969.663$ & $2,238.954$ & $4,208.617$ \\
\hline
\end{tabular}

\subsection{Transport and land use dimension}

Belem emerged at the mouth of the Amazon River, in the interest of ensuring the defense and with prospects of economic control of the region. Economic expansion brought new phases of occupation until the 19th century, with water transportation the main support of regional access. During World War II were donated lands for military purposes in Belem, on the border of the first phase of urban occupation; the so-called institutional belt, currently, named transition area. After this belt, in the following decades, from 1950 to 1970, the urban road network has expanded to new roads, which came to be stimulated by new economic and housing investment to the present day. Urban occupation occurred faster than expansion of transport network, emphasizing problems of accessibility and transportation supply, mainly in periphery areas, with individual transportation predominating [29]. The intermodality was configured by the combined use of road and water transportation of passengers and cargoes, but without integrated system planning [30]. Only in the last two decades that the integrated planning vision came with the spatial configuration of the system shown in Fig. 1, with interconnections to bus corridors integration on mainland and physical connection in some ports.

\subsection{Social dimension}

The differences in accessibility of central and periphery areas are justified by significant investments in the former and to the accelerated and disorderly growth of the latter. This makes the location as a determinant social production to social exclusion. Thus, the provision of urban structure, together with urban transport network, are characterized for three urban space units occupied: central area, transition area (where is the institutional belt) and expansion area. As it moves away from central area, there is a reduction of road network, transportation supply and employment opportunities. This configures a spatial segregation process whose models are treated on several academic studies, standing out, in the case of insular area of Belem, the trip reasons. A 2009 study [28] indicated the main reasons for traveling from islands to mainland were work (20.1\%); health $(10.4 \%)$ and study $(9.3 \%)$; while what attracted the people from mainland to islands was leisure activity $(47.97 \%)$, firstly. Regarding income, in the islands, it has been estimated that $55 \%$ of the population has average income from \$US48 up to \$US146, over this decade; while on mainland, the average income in the last decade was \$US517. Income is important to access transportation services, 


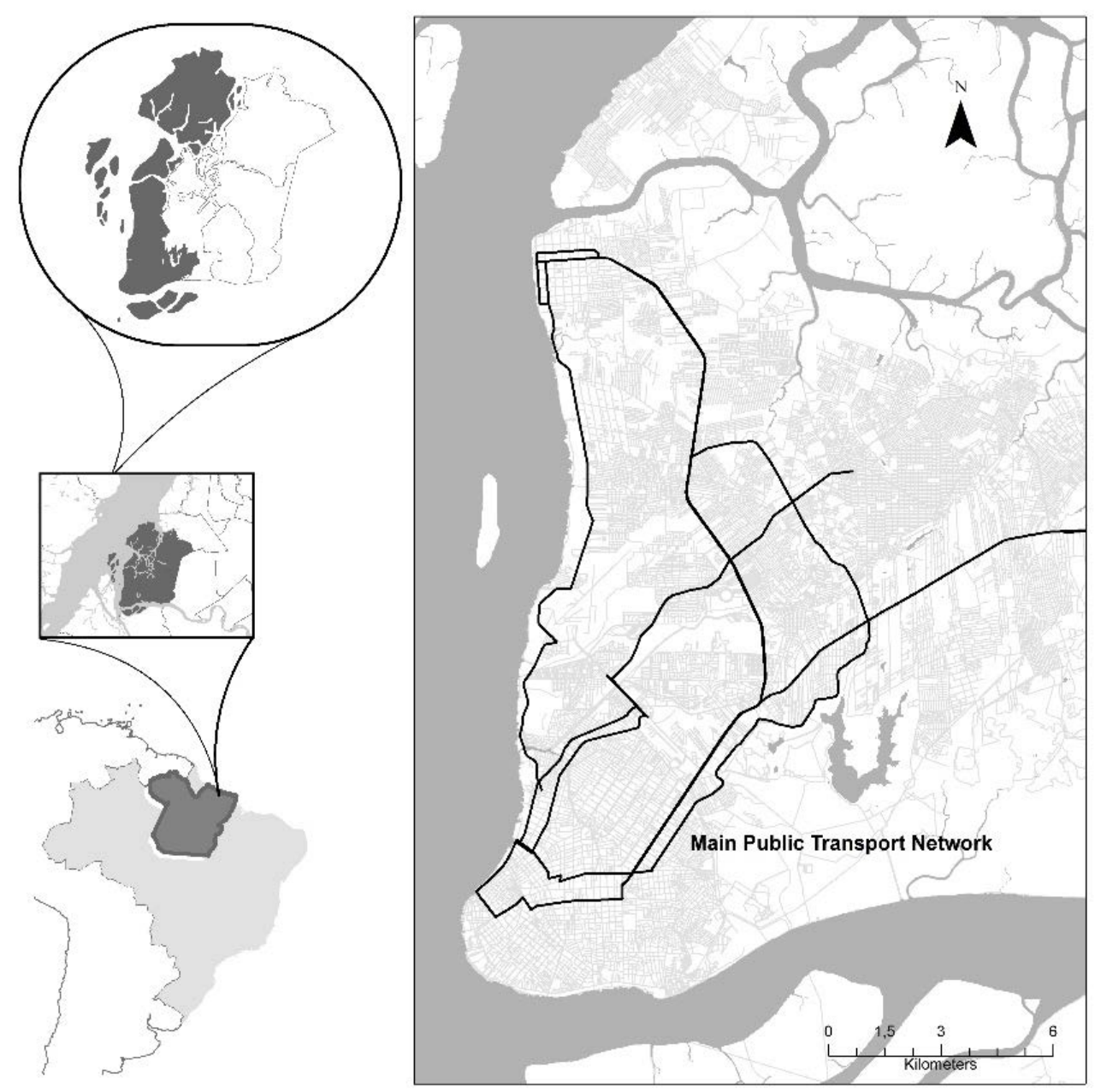

Figure 1: Main public transport network. Bus corridors in the city of Belem.

considering generalized costs, determinants to reach equity, accessibility and mobility, social dimensions of transportation. The most recent studies show that there were no significant changes in the data presented [31]-[33].

\subsection{Environmental, economics and transport policies}

In Amazonian city, is crucial to consider environmental or ecological dimension of impacts of human activities in changing local and global environments. In Belem case, the transportation system clutter and, its consequent lack of integration, demonstrates a lack of public policies. The economic structure is sustained by the third sector, as commerce, services and government activities, with $91 \%$ of total jobs, with one-third of all jobs concentrated at Belem's downtown and its surroundings [33]; which raises the importance of integrating waterway transportation to promote social and economic inclusion of island population and 
to encourage tourism flow that comes from mainland. There are many issues to be determined in pursuit of policies for integrating transport, economy and environment, despite the specific focus on environmental and economic issues have triggered the first integration studies. Among them, to making decision on the governance of the transport system, municipal or metropolitan, for the financing of transport and infrastructure. In fact, there are no defined and effective public policies capable of undertaking intermodal integration.

\section{DISCUSSION}

The goal is to provide higher service mobility at lower costs, but also improving the quality of transportation services for all city of Belem, in face to evasion of demand from public transport to individual transportation. Thus, cconsidered the challenges to be faced by public management by the integration of waterway transport mode to the urban transport system, the analysis of the integrated dimensions undertaken on the case study shows several important aspects for the feasibility of using that mode in the city region.

The first challenge we identified is the need to integrate the waterway mode in the city transportation planning process and the creation of intermodal services in the nodes of connection to all existing modes Moreover, from an operational perspective, the physical and tariff point of view are also important to the total integration. In this case, it is necessary proper cooperation and support from different levels of government, with adequate institutional structure and planning.

The second challenge is the need to expand transportation infrastructure to support population growth and to be adapted as an organizational element in the urban sprawl process and land use regulator. The inclusion of this new mode in the global transport system, the city accessibility levels could increase opportunities for employment and people's access to basic health and education services. In a social dimension, the challenge is the need for social inclusion of people nowadays outside the public transport system, for economic and social reasons. Hence, investing in accessibility and financial conditions, as well as in transport support infrastructure, the global transportation system become safer and inclusive.

The third challenge, there is specific need to elaborate and support the transportation public policies for the sustainable mobility by integrating the economic and environmental policies in the global policy of the city for sustainability goals. The map of Fig. 2 shows the eight island areas of Belem with regular water transportation displacements observed in loco nowadays. The map identifies the waterway transport routes and the respective areas of origin and destination. If the waterway transport routes links to mainland could be connected to the main public transport network of the city (showed in Fig. 1), an integrated intermodal transport network could be proposed as shown in Fig. 3. That suggests an integrated public transport system combining waterway transport and urban transportation and could serve the region in an integrated way, if the waterway routes observed in the areas of Fig. 2 is connected in modal transfer points to the public transport network of Fig. 1. Obviously, found as possible good solution for the transportation modes of the city, however, this is a proposal that needs more specific financing and operational studies.

Finally, in Amazonian cities, integration depends not only in elaboration, but also in the application of urban transport policies considering water transport within urban mobility systems. Most of big cities of Amazonia were founded along banks of rivers, which indicates their natural potentiality for use waterway transport. There is also the need to change modal culture, both population and technicians of government bodies. In short, as pointed in this article, all dimensions of analysis need to be met and the possibility of different modes, disconnected nowadays, should be a priority for modal integration. 


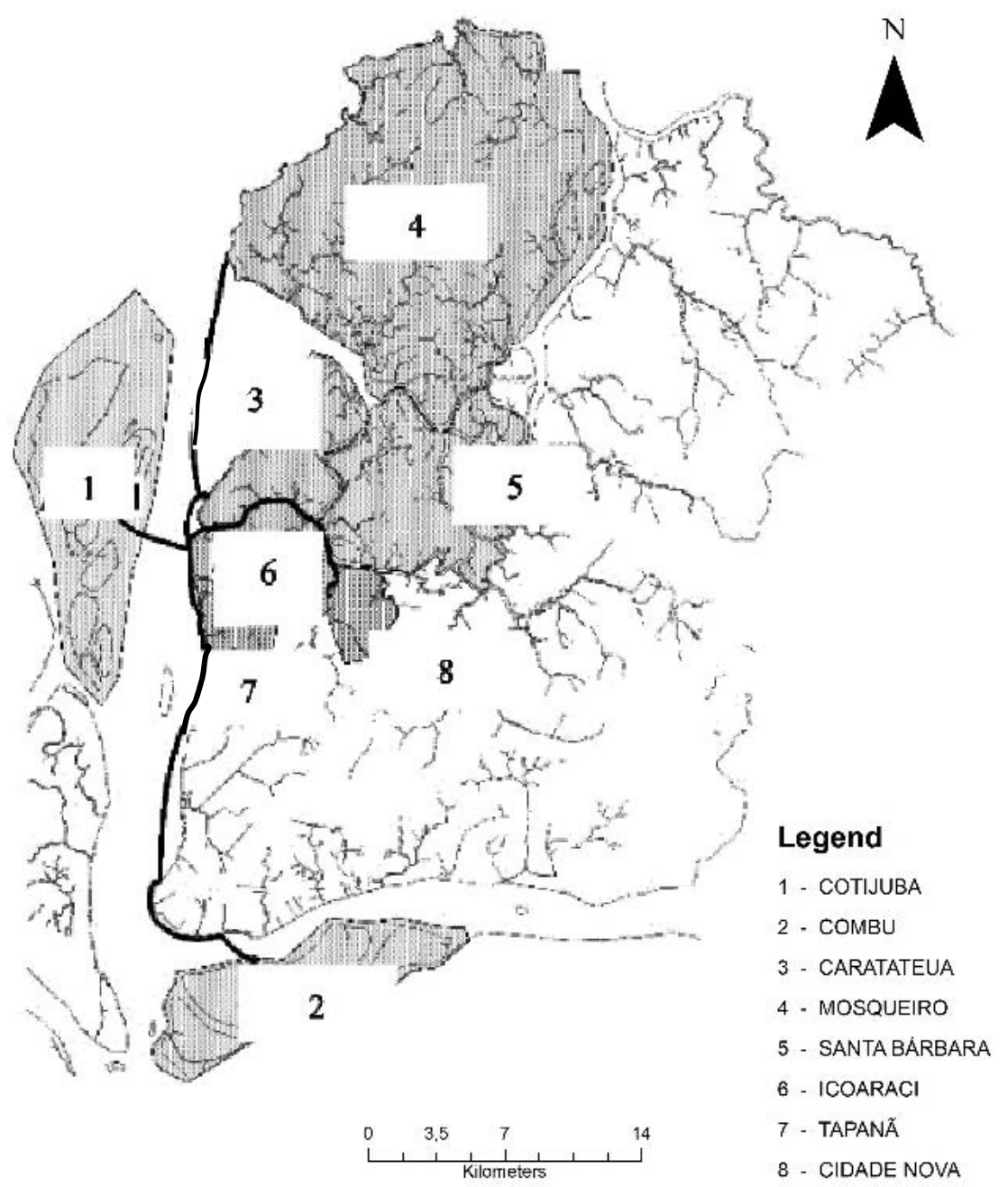

Figure 2: Waterway transport routes from mainland to islands.

\section{CONCLUSION}

This article has taken a future perspective on transport and sustainability, drawing attention to possibility in the use of intermodal integrated transport in Amazonia, with a case study in Belem, Brazil. As any realistic consideration of the future, no guaranteed conclusion can be drawn directly from this study. Although, the study is very important to the understand some scenario including the waterway mode in the transport system and in each analysis dimension has allowed to observe the critical aspects and to foresee changes in the development process of the urban area, inducing the configuration identified in the Fig. 3.

This study confirm that the intermodal physical integration of the waterway mode is possible, but requiring complementary studies to analyse the economic and operational viability. Moreover, a more equity and sustainable urban environment could be developed by an integrated transport strategy extended to the waterfront of the city. 


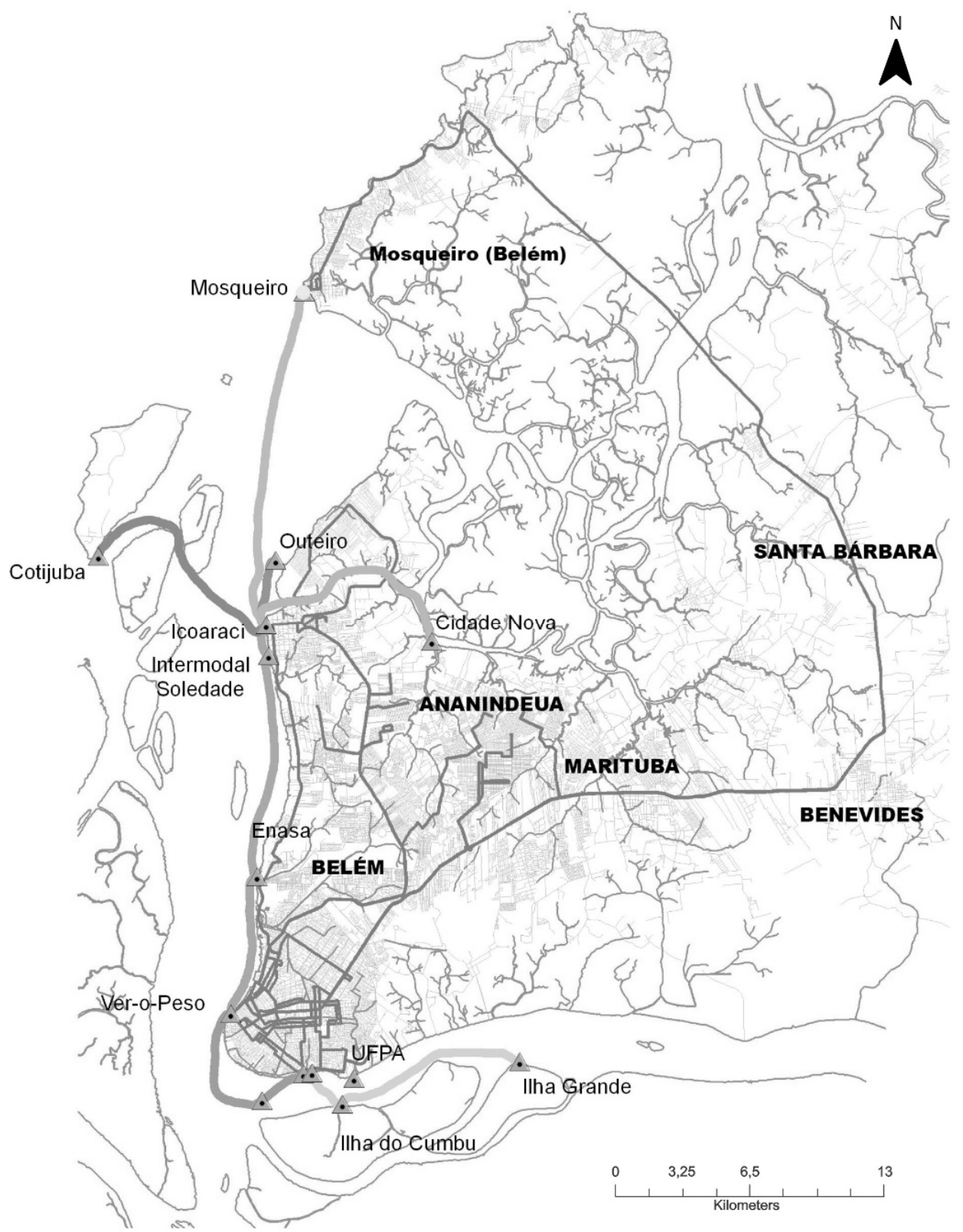

Figure 3: Waterway transport integrated to urban transportation. A draft system.

Finally, integration of all modes of transport is a challenge for public transportation policies of the city and for all the region. Nowadays, the situation, in face of the social context empirically observed, looks like a very clear the necessity of investments in new transportations solutions, mainly, for the attendance of economic activities and population; 
that has the central urban area as destination for the most basic activities. In general, the integration of systems seems possible, but there are some specific questions to be solved and, which can be explored in later studies.

\section{REFERENCES}

[1] Potter, S., Vital Travel Statistics, Landor: London, 1997.

[2] Royal Commission on Environmental Pollution (RCEP), Proceedings of 20th Report: Transport and the Environment, HMSO: London, 1997.

[3] Banister, D. \& Button, K., Transport, the Environment and Sustainable Development, Spon Press: UK, 1993.

[4] Viegas, J.M., Transport policy development in Europe 1950-2020. Proceedings of Fifty Years of Transport Policy, European Conference of Ministers of Transport, OECD Publication Services: Paris, pp. 105-115, 2003.

[5] ECMT, Synthesis. Presented at 87th Session of the Council of Ministers. Proceedings of Fifty Years of Transport Policy, European Conference of Ministers of Transport, OECD Publication Services: Paris, pp. 1-9, 2003.

[6] Stead, D. \& Meijers, E., Policy integration in practice: Some experiences of integrating transport, land-use planning and environmental policies in local government. Proceedings of Berlin Conference on the Human Dimensions of Global Environmental Change: Greening of Policies - Interlinkages and Policy Integration, Delft University of Technology, OTB Research Institute for Housing, Urban and Mobility Studies, 2004.

[7] Geerlingsa, H. \& Stead, D., The integration of land use planning, transport and environment in European policy and research. Transport Policy, 10, pp. 187-196, 2003.

[8] Saleh, W. \& Bel, M., Developing urban transport policies and strategies. Proceedings of Institute of Transport Studies, I.T.S.: Australia, 1997.

[9] Marti, C. \& Weidmann, Z., Understanding public transport and built environment integration at the neighbourhood scale: Towards a method for holistic quantitative assessment. Proceedings of 16th Swiss Transport Research Conference, Monte Verità, Ascona, 2016.

[10] Grayling, T., Social justice in and upwardly mobile society. Sustainability and Social Justice, ed. J. Foley, IPPR, pp. 24-37, 2004.

[11] Høyer, K.G., Sustainable mobility: The concept and its implications. PhD thesis, Department of Environment, Technology and Social Studies Roskilde University Roskilde, Denmark Department of Environmental Research Western Norway Research Institute, Sogndal, 216 pp., 2000. (In Norwegian.)

[12] Gudmundsson, H., Making concepts matter: Sustainable mobility and indicator systems in transport. International Social Science Journal, pp. 199-217, 2004. DOI: 10.1111/j.1468-2451.2003.05502003.x. Accessed on: 20 Feb. 2019.

[13] Wagner, P. \& Wegener, M., Environment models experiences with an integrated microscopic approach. Urban Land Use, Transport and disP 170, 3, pp. 45-56, 2007.

[14] Rotmans, J. \& Loorbach, D., Transition management: Reflexive governance of societal complexity through searching, learning and experimenting. Managing the Transition to Renewable Energy, eds J.C.J.M. van den Bergh \& F.R. Bruinsma, Edward Elgar: Cheltenham, UK, pp. 15-46, 2008.

[15] Santos, M., A natureza do espaço: técnica e tempo, razão e emoção, EDUSP: São Paulo, 1996. 
[16] Giovinazzi, O., Port cities and urban waterfront: Transformations and opportunities. Journal of Mobility, Land Use and Environment Journal, 3, pp. 57-64, 2010.

[17] Greiving, S. \& Wegener M., Integration of transport and land use planning: state of the art. Proceedings of 9th World Conference on Transport Research, Elsevier, 2003.

[18] Pillay, K. \& van Zyl, O., Towards a modal integration strategy for Gauteng, action in transport for the new millennium. Proceedings of American Society of Civil Engineers: Urban Public Transportation Systems, pp. 179-192, 2013.

[19] US Environmental Protection Agency, Our built and natural environment, A Technical Review of the Interactions Between Land Use, Transportation, and Air Quality. Washington, DC, p. 9, 2001.

[20] Chakwizira, J., The contribution transport governance to socio-economic development in South Africa. Proceedings of 28th Annual Southern African Transport Conference (SATC), Pretoria, South Africa, 2009.

[21] Cervero, R., Road expansion, urban growth and induced growth. Journal of the American Planning Association, 69, pp. 145-163, 2003.

[22] Bongardt, D., Schmid, D., Cornie, H. \& Litman, T., Sustainable transport evaluation. GIZ, Eschborn, Germany, 2001.

[23] Low, N., Is urban transport sustainable? Making Urban Transport Sustainable, eds N. Low \& B. Gleeson, Palgrave Macmillian: New York, pp. 1-22, 2003.

[24] Kennedy, C., Miller, E., Shalaby, A., Maclean, H. \& Coleman, J., The four pillars of sustainable urban transportation. Transport Reviews, 25(4), pp. 393-414, 2005.

[25] Pereira, J.C.M., Importância e Significado das Cidades Médias na Amazônia: uma abordagem a partir de Santarém (PA), Belém - Pará, Master's thesis, Programa de PósGraduação em Desenvolvimento Sustentável do Trópico Úmido, NAEA/UFPA, Belém, 139 pp., 2004. (In Brazilian.)

[26] Cardoso, A.C. \& Miranda, T.B., Relações entre invisibilidade social, alterações no meio físico e produção do espaço subordinada em Belém (PA). Proceedings of Seminário Internacional América Latina: Políticas e conflitos contemporâneos, Belém, Brazil, 2017.

[27] D-Fluvial, Análise Preliminar de Impactos Ambientais do Projeto D-Fluvial. Second Partial Technical Report, FINEP/UFPA/UNAMA, Belém, 2009.

[28] Japan International Corporation Agency (JICA), Secretaria de Desenvolvimento Urbano do Estado do Pará - SEDURB \& Companhia de Habitação do Estado do Pará (COHAB-PA). Estudo Preparatório para o Projeto do Sistema de Transporte por Ônibus da RMB, Belém, 2009.

[29] Trindade Júnior, S.C., Formação Metropolitana de Belém (1960-1997), Paka-Tatu: Belém, 2016.

[30] Morotomi, I., Tourinho, H.Z. \& Lôbo, M.A.A., BRT e configuração da estrutura intraurbana: o caso da Região Metropolitana de Belém-Brasil. Proceedings of 8th Congresso Luso-Brasileiro para o Planeamento Urbano, Regional, Integrado e Sustentável, Coimbra, Portugal, 2018.

[31] Lerner, J. et al., Projeto operacional dos corredores BRT de transporte de passageiros de Belém, 2013.

[32] EGL Engenharia, Estudos de Implantação do BRT Belém - Projeto Funcional, Modelo de Gestão, Remuneração e Desenho da Outorga (Concessão) do Sistema Integrado de Transporte de Passageiros de Belém-PA, 2015.

[33] Instituto Brasileiro de Geografia e Estatística - IBGE, Censo demográfico 2010, Rio de Janeiro, 2010. 